GRØNLANDS GEOLOGISKE UNDERSØGELSE G E U S RAPPORT NR. 23

Report file no.

22345

The Geological Survey of Greenland

Report no. 23

\title{
The Precambrian rocks of the Egedesminde-Christianshåb area, West Greenland
} by G. Henderson 


\section{Grønlands Geologiske Undersøgelse \\ Østervoldgade 10, Dk-1350 Copenhagen K \\ Recent publications}

\section{Bulletins}

\section{reprinted from Meddelelser om Gronland}

No. 70 Plutonic development of the Ilordleq area, South Greenland. Part II : Latekinematic basic dykes. 1968 by J. Watterson.

No. 71 Contrasted types of metamorphism of basic intrusions in the Precambrian basement of the Tasîussaq area, South Greenland. 1968 by P. R. Dawes.

No. 72 Evolution plutonique et structurale de la presqu'île d'Akuliaruseq, Groenland méridional. 1969 by F. Persoz.

No. 73 Observations on some Holocene glacier fluctuations in West Greenland. 1968 by $\mathrm{A}$. Weidick.

No. 74 Precambrian organic compounds from the Ketilidian of South-West Greenland. 1968 by K. Raunsgaard Pedersen and J. Lam.

No. 75 Contributions to the mineralogy of Ilimaussaq Nos 9-11. 1968.

No. 76 A study of radioactive veins containing rare-earth minerals in the area surrounding the Ilimaussaq alkaline intrusion in South Greenland. 1968 by J. Hansen.

No. 77 Anorthosite xenoliths and plagioclase megacrysts in Precambrian intrusions of South Greenland. 1968 by D. Bridgwater and W. T. Harry.

No. 78 Homogeneous deformation of the gneisses of Vesterland, South-West Greenland. 1968 by J. Watterson.

No. 79 A tetragonal natrolite. 1969 by E. Krogh Andersen, M. Danø and O. V. Petersen.

\section{Miscellaneous Papers}

reprinted from various journals

No. 57 Potassium-argon age studies in West Greenland. 1968 by O. Larsen and J. Møller.

No. 58 Early shell growth and structures of the septa and the siphuncular tube in some Maastrichtian ammonities. 1968 by T. Birkelund and H. J. Hansen.

No. 59 The Precambrian stratigraphy of western Greenland. 1968 by T. C. R. Pulvertaft.

No. 60 Niobium mineralization in the Ilímaussaq alkaline complex, South-West Greenland. 1968 by John Hansen.

No. 61 An Atlantic Middle Cambrian fauna from North Greenland. 1969 by V. Poulsen. 
THE PRECAMBRIAN ROCKS OF THE EGEDESMINDE-CHRISTIANSHÅB AREA, WEST GREENLAND

by

G. Henderson

With 7 figures and 1 map

1969 


\begin{abstract}
Most of the area described consists of quartzo-feldspathic gneisses with zones and bands of mica schist and pelitic gneiss, amphibolite, and a few thin marble and calc-silicate bands. Granitic rocks are also present, but are of minor importance. A large quartz diorite body is thought to represent a folded and metamorphosed intrusive sheet. Two metamorphic complexes are present, a predominantly amphibolite facies complex and a granulite facies complex. Migmatites are a prominent feature in some areas of mica schist and pelitic gneiss. At least two, and probably three, deformation phases are represented. A good correlation has been established with adjoining areas.
\end{abstract}




\section{CONTENTS}

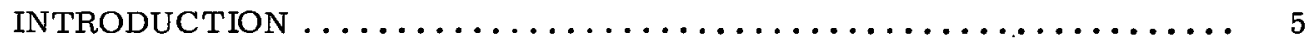

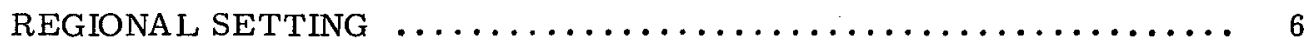

LITHOLOGY. ............................ 7

The Egedesminde complex ................. 7

The Isortoq complex .................... 13

Metadolerites and discordant amphibolites ........... 15

Lamprophyre dyke ....................... 17

Dolerite dykes ........................... 18

STRUCTURE $\ldots \ldots \ldots \ldots \ldots \ldots \ldots \ldots \ldots \ldots \ldots \ldots \ldots \ldots \ldots \ldots \ldots \ldots$

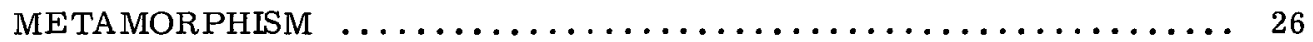

Metamorphic facies ...................... 26

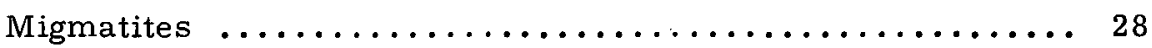

COMPARISON WITH ADJOINING AREAS $\ldots \ldots \ldots \ldots \ldots \ldots \ldots \ldots$

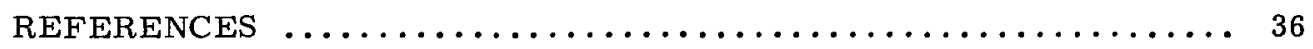




\section{INTRODUCTION}

The area described is situated on the west coast of Greenland between $68^{\circ} 00^{\prime}$ and $69^{\circ} 00^{\prime} \mathrm{N}$ and between $49^{\circ} 55^{\prime}$ and $53^{\circ} 50^{\prime} \mathrm{W}$. It is bordered on the east by the Inland Ice and on the west by the Davis Strait.

The relief is low to moderate, the highest country occurring in the north-east of the area, where one peak is $674 \mathrm{~m}$ and numerous others exceed $500 \mathrm{~m}$. A few peaks in the south-east of the area exceed $500 \mathrm{~m}$. Throughout most of the rest of the area the terrain does not exceed a few hundred metres in height.

Much of the area is accessible by ship. However, one block of country is difficult of access, and the central part of this block can only be reached after a long journey on foot, or by helicopter. This is the country lying between the fjord Arfersiorfik and Sydostbugt. Part of this is occupied by an extensive plain known as Lersletten, which is floored by marine Quaternary clay.

Major glaciers are restricted to two parts of the area. In the north-eastern part the twin glaciers Alángordliup sermia and Sarqardliup sermia discharge into southern arms of Jakobshavns Isfjord. In the eastern central part of the area the glacier Nordenskiolds Gletscher discharges into Tasiussarssuaq, an inland arm of Arfersiorfik. Tasiussarssuaq is almost completely enclosed, with the result that there is a very strong tidal race in the narrow outlet Sarfarssuaq. The channel can, however, be passed by small ships at slack water. At the time of the writer's visit the glacier showed little sign of activity.

The mapping was undertaken in the summer of 1966 as part of the programme for producing 1:500000 maps of West Greenland. One day was spent subsequently in the area at the start of the 1968 season for the purpose of collecting additional samples. Before the field season commenced a preliminary photogeological interpretation was undertaken, and during the mapping all observations were recorded directly on the aerial photos. The photos proved to be of limited value for interpretation. Although they were of considerable value in mapping the regional structure, they proved disappointing when it came to distinguishing the different lithological units. The rather low terrain that characterizes most of the area has been moulded 
by ice and is covered by lichen. Because of these two factors the individual lithological units do not usually have a characteristic form and tone on the aerial photos.

\section{REGIONAL SETTING}

The area consists almost entirely of Precambrian crystalline rocks, which form part of the Nagssugtoqidian fold belt as defined by Ramberg (1949). Numerous K/Ar determinations made on rocks from this fold belt in recent years (Larsen and Mфller, 1968) give very consistent values, which lie within the range 1650 to $1790 \mathrm{~m} . \mathrm{y}$. Ramberg recognized two complexes within the area, the Egedesminde complex (amphibolite or epidote-amphibolite facies) and the Isortoq complex (granulite facies). The Egedesminde complex constitutes most of the area mapped. The Isortoq complex occupies the south-western corner of the map.

The reconnaissance map by Noe-Nygaard and Ramberg (1961) of the entire coastal belt from Disko Bugt to south of Godthåb has formed the basis of all subsequent work in this part of West Greenland, and the present writer freely acknowledges his indebtedness to this source.

The rocks in the island group extending from Anârssuit to Eqûtit kangigdleq, north-east of Egedesminde, formed the subject of a detailed study by Ellitsgaard-Rasmussen (1954). These rocks were included in the Egedesminde complex by Noe-Nygaard and Ramberg (1961).

Economic investigations have recently been undertaken in the central part of the Lersletten area by Kryolitselskabet Øresund A/S. Reports on the work are filed at the Survey.

A preliminary account of the reconnaissance mapping undertaken by the writer is to be found in Henderson (1966). 


\section{LITHOLOGY}

The Egedesminde complex

Quartzo-feldspathic gneiss, mainly of granodioritic composition, is the dominant rock type in the Egedesminde complex. This gneiss varies considerably in aspect throughout the area. In some localities, e.g. the Anoritôq peninsula on the east side of Sydostbugt and the area due north of Christianshåb, it shows very strong compositional banding, which is due to varying amounts of mafic minerals, both biotite and hornblende being present. Amphibolite bands are common. Amphibolite lenses are very abundant in certain areas, where they occur in broad zones (e.g. Tasiussarssuaq and Qardlutôq in the inner part of Arfersiorfik fjord). In future detailed mapping these zones will probably be useful in outlining the regional structure. Agmatite is restricted to a few localities, the best development being around A kugdlît in Sydostbugt.

In some places the gneiss only shows weak to nebulitic banding, and is locally homogeneous. Much of the gneiss forming the peninsula north of Laksebugt is of this type.

Banded gneiss with lit-par-lit banding is developed in parts of the area south and west of Ikamiut.

In the inner part of Arfersiorfik a zone of basic gneiss of a type not found elsewhere in the area was encountered. This is a hornblende gneiss rich in microcline. It contains numerous pegmatites.

Augen gneiss occurs in one area in the northern part of Lersletten. In some places the foliation disappears, the rock being a dark granodiorite with randomly oriented feldspar megacrysts, some of which are euhedral.

Belts of mica schist and pelitic gneiss are prominent in the area around Sydostbugt. They form concordant layers in the quartzo-feldspathic gneiss, and are often associated with zones of strongly banded gneiss (e.g. around Christianshåb). The schists contain quartz, plagioclase, biotite, muscovite, sillimanite and garnet. The proportions of the minerals vary, however, from place to place, and one or more of these minerals may be absent. Pelitic gneisses in the northern part of the bay Nivâp pâ and south of Ikamiut were found to contain potash feldspar in varying amounts, as well as plagioclase. 


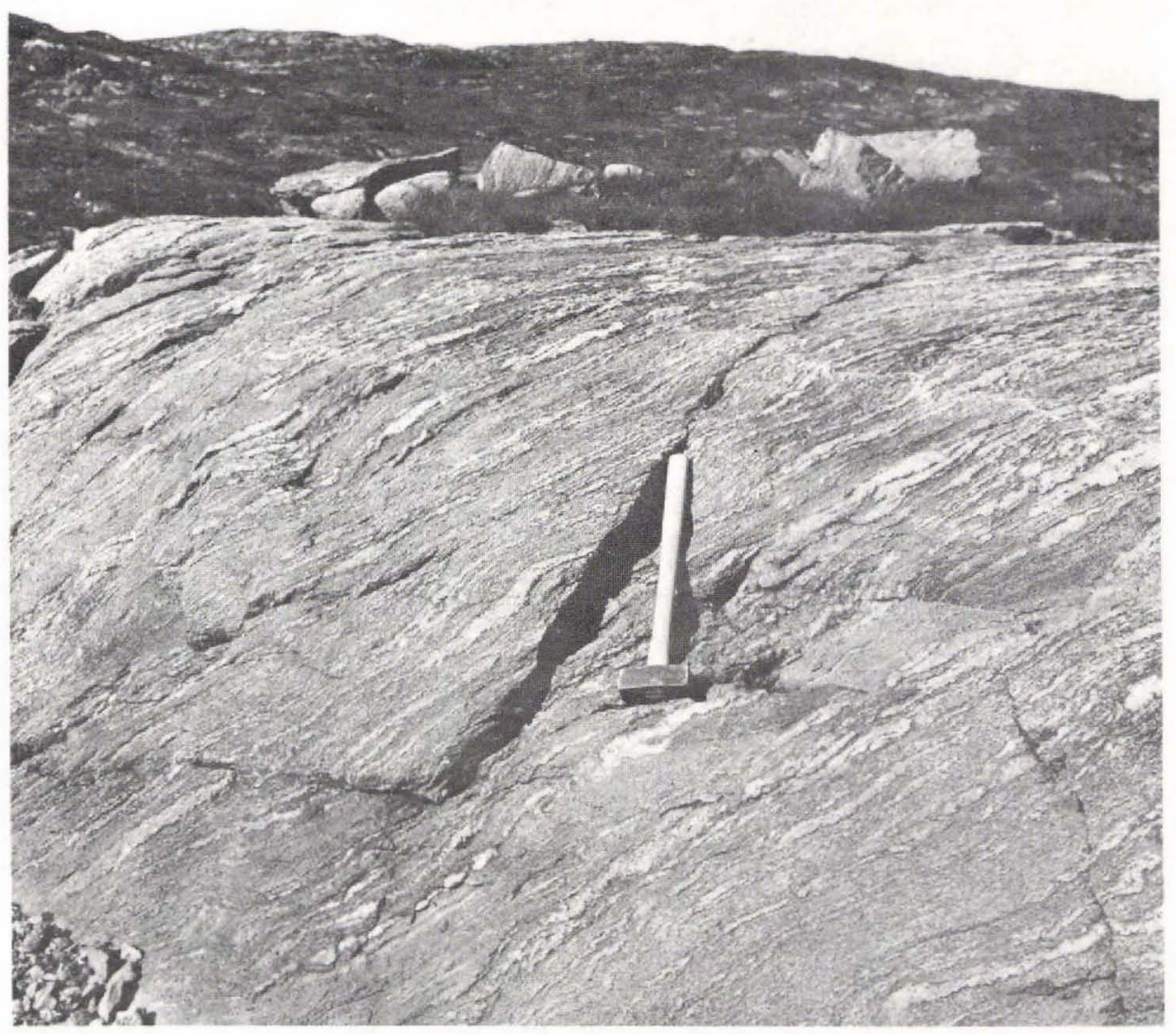

Fig. 1. Layered migmatite. Mica schist with lenticular pegmatoid seams. South-west of Ikamiut. (GH. 04.05.1966.)

A characteristic feature of the schists and pelitic gneisses in many places is the presence of numerous bodies of quartzo-feldspathic rock, ranging in character from pegmatite to leucocratic gneiss. The resulting mixed rock has the character of a migmatite. These bodies are generally concordant and range in size from small lenses (fig. 1) to sheets of considerable lateral extent and a thickness of a metre or more (fig. 2). In places they carry garnets, and felted masses of sillimanite are promiment in pegmatite lenses in schists and pelitic gneisses along the southern side of Sydostbugt. 


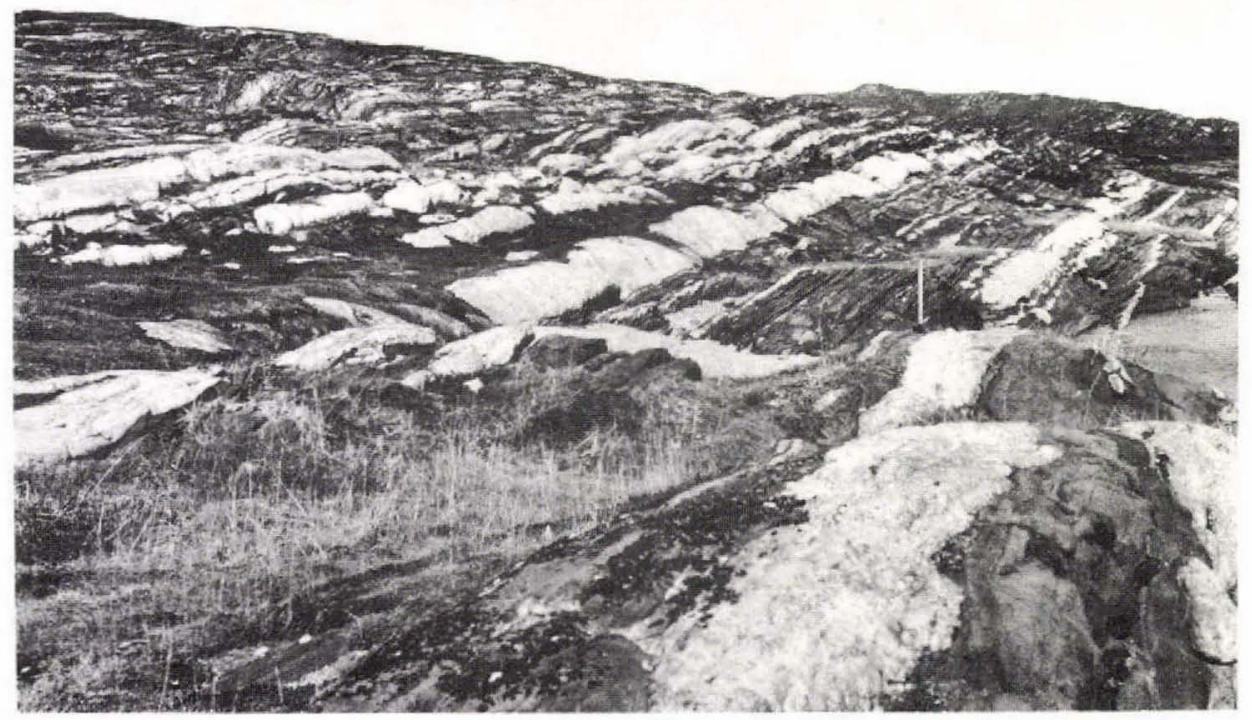

Fig. 2. Layered migmatite. Pelitic gneiss with pegmatoid sheets. Southwest end of Kangilinâq peninsula. (GH. 01.09.1966.)

The abundant presence of pegmatites in schists in this area has already been noted by Ramberg (1956, fig. 6 and pl. 1, figs. 1 and 2).

Amphibolite bands, some of which are thick, occur in association with the schists around Sydostbugt. These contain pegmatites in places, but the proportion of pegmatite is less than it often is in the schist; the intimate association between pegmatite and foliation seen in the schists is lacking in the amphibolite, where the pegmatites are more random in their occurrence. Ramberg (1956, pp. 189-90) remarks, "In contrast to the crosscutting pegmatites which are typical of amphibolites and other basic rocks, most pegmatites in the mica schists are conformable, lenticular or pinching and swelling bodies..." . He illustrates this with a sketch (fig. 6) of an area on the southern side of Laksebugt.

Marble and calc-silicate bands occur in the peninsula south of Christianshåb. These are thin. A section across one limb of a closure 
inland from Kangerdluluk gave a total thickness of about $30 \mathrm{~m}$ of very variable impure marble and calc-silicate rocks, with hornblende, tremolite and diopside.

The schists that form the two schist belts north of the lake Umataussap taserssua clearly have a somewhat different bulk chemical composition from the schists around Sydostbugt. At several localities along these schist belts zones of light-coloured schist with cummingtonite were observed. One other occurrence of cummingtonite was found in schists. This was in light-grey schists associated with a narrow zone of metasediments consisting of marble, calc-silicate rocks and various schists on the eastern end of the island of Manitsoq, north of Egedesminde.

At the southern end of a group of hills occurring between Sydostbugt and the western end of Tasiussarssuaq there is a zone of schist and amphibolite situated along strike from the northernmost of the two schist belt referred to in the preceding paragraph. The southern face of the outcrop consists of white quartz-plagioclase-microcline-biotite-muscovite schist, which contrasts strongly with the black amphibolite band immediately to the north. The amphibolite is succeeded northwards by a narrow zone of pelitic schist with staurolite, sillimanite and garnet. This was the only locality in which staurolite was found.

Schists with a mineral assemblage similar to that of the schists around Sydostbugt are fairly common in the western part of the map. They are, however, rather thinly developed in this area. The associated amphibolite bands are numerous, and in places are very thick, so that they are much more prominent than the schists here.

Bands of schist and amphibolite are common in the inner part of the fjord Arfersiorfik. Some of these are clearly of considerable lateral extent. The continuation of the three bands mapped on the north-east side of the inner end of the fjord can be traced along the southern side of the fjord to the west. The northernmost of the three bands on the north-east side of the fjord comprises a variety of rock types: garnet-biotite schist, impure marble and calc-silicate rocks, and amphibolite. Westwards down the fjord this is represented by two bands consisting of garnet-biotitesillimanite schist, amphibolite and minor calc-silicate horizons. The two bands are separated by a zone of banded gneiss. 
Granitic rocks occur in various parts of the area. Most of the island of Manitsoq is composed of granite, in places with porphyritic texture. West of the locality Qaersulik in the western part of Lersletten there is a hill that was visited mainly because the aerial photos suggested the presence of a large fold here, with closure to the east. Much of this hill is composed of granitic rocks, which range from medium-grained granite with no foliation, except for a slight dark streakiness locally, to weakly banded granitic gneiss, the weakly banded rocks being found mainly along the outer margin of the body, which is bordered by schists. The few measurements obtained suggest that there is a fold here, but it is much less impressive than would be expected from the photos.

An extensive concordant and folded sheet composed of granitic rocks occurs in the western part of the bay Nivâp pâ in western Sydostbugt. On the southern side of the bay the granitic rocks are in contact with amphibolite. Close to the margin the rock is a weakly banded granitic gneiss, which passes into a faintly foliated granite farther away from the contact. On the northern side of the bay also, the rocks range from granite to granitic gneiss.

Occurrences of granitic rocks were noted to the north-east of Kangâtsiaq, on the islands of Oqaitsut and Arqitsoq, and south of Christianshåb. At all these localities the rocks showed foliation to a greater or less degree.

Granite collected by Giesecke (1910) from the island of Akúnâq was shown by Noe-Nygaard (1944) to be typical rapakivi granite.

The present writer did not examine this island in detail, and cannot therefore state whether or not rapakivi granite occurs in situ here, but it could be noted that no rapakivi granite was observed in outcrop anywhere else in the area mapped.

A large folded quartz diorite body dominates the inner part of Arfersiorfik, in the south-eastern corner of the map. On its northern side it is in contact with the hornblende gneiss rich in microcline mentioned previously. Dips in the vicinity of the contact on each side of the fjord range from moderate to steep north-north-west to vertical. From here southwards as far as the innermost part of the fjord, south of the present map, the body forms the highest structural unit and rests on a lightcoloured quartzo-feldspathic gneiss. 
The central part of the body is completely homogeneous, apart from the presence of numerous dark lenses and schlieren. There is no foliation to be seen at all, and in the field the rocks in this area have a definite igneous appearance.

Only one sample (88024) is available from this part of the body. It consists of a hypersthene-bearing quartz diorite with part of a dark lens. The host rock consists mainly of plagioclase, hornblende, quartz, hypersthene and biotite. The hypersthene shows replacement by talc, tremolite, green hornblende and ore. The grain size of the constituent minerals varies, but many of the plagioclase grains are from a millimetre up to several millimetres in length. One grain is over $5 \mathrm{~mm}$ long. One hypersthene grain is $5 \mathrm{~mm}$ long. The host rock has thus a rather coarse appearance. The dark lens consists of amphibolite. Diopside is present, but is subordinate to hornblende in amount. There are a few large grains of hypersthene. The lens is mainly fine-grained, the grain size of most of the minerals being well below $1 \mathrm{~mm}$.

The marginal part of the body varies in character. Due north of the headland with the height point $320 \mathrm{~m}$ on the north side of the fjord, much of the rock is homogeneous, but there is some weak compositional banding on the headland itself. West of the bay Qilalugkat kangerdluat, quartz diorite with small mafic lenses passes down into a dark gneiss with compositional banding and garnet clusters up to several centimetres across, which in turn overlies garnetiferous biotite gneiss with quartzofeldspathic lenses. On the eastern side of this inlet the section southwards across the small peninsula comprises dark gneiss, some with garnet, banded gneiss, some of which is light grey, and a thin garnet-biotite schist band. The bands of dark gneiss are so similar to much of the rock forming the margin of the body elsewhere that this varied zone has been mapped as part of the quartz diorite body. On the south side of the peninsula the dark rocks overlie a very light-coloured quartzo-feldspathic gneiss.

Compositional banding was observed in several sections across the marginal part of the body examined to the south of present map. In one of these sections a zone of dark garnetiferous gneiss with a thin schist band was seen a considerable distance above the base of the body. The rocks between this zone and the margin are banded to homogeneous dark rocks, which clearly belong to the main body. 
Several thin sections of samples from the quartz diorite body were cut, but the only sample with hypersthene is that from the central part of the body on the north side of the fjord. In others the mafic minerals are hornblende, biotite, and in one sample (88025), cummingtonite, which is partly replaced by, and intergrown with, green hornblende. All of these are from points closer to the margin of the body than the hypersthene-bearing sample.

At many localities a thin band of garnet-biotite schist marks the contact between the quartz diorite and the underlying light-coloured gneiss.

This body is probably a continuation of the diorite body mapped in the Agto area south-west of the present map (Jensen, 1968). It is considered to have been a thick, very extensive intrusive sheet, which has undergone folding and metamorphisism. The centre of the body has clearly been more resistant to the metamorphism than the margins.

The Isortoq complex

Quartzo-feldspathic gneiss, mainly of quartz dioritic composition, is the dominant rock type in the part of the Isortoq complex that is represented on the present map. When viewed from a distance this gneiss is brown in colour, in contrast to the light-grey granodioritic gneiss of the Egedesminde complex. The difference is also visible in hand specimen, gneiss from the Isortoq complex commonly being light brown, with a granular appearance.

The gneiss often shows a strong compositional banding. Amphibolite bands and lenses are common, and in some places are very abundant.

The boundary between the two complexes is transitional, and clearly cuts across the regional structure. The boundary shown is based on the boundary on the map by Noe-Nygaard and Ramberg (1961), with minor modifications.

A prominent feature of the rocks in the western part of the island of Qôrsungnitsoq is the presence of zones of light-coloured often lit-par-lit banded gneiss, which are intercalated with darker banded gneiss. These 
lit-par-lit gneisses are rich in microcline. The brown gneisses of the Isortoq complex are typically devoid of potash feldspar as independent grains (see Ramberg, 1949, p. 321 and 1951 p. 30). They do, however, contain very small or even minute amounts of potash feldspar. In order to make this more readily visible a number of thin sections were etched over 38-40\% hydrofluoric acid and then treated with sodium cobaltinitrite, which stains potash feldspar yellow. It could then be seen that the potash feldspar is locally present along grain boundaries. It can also be seen replacing plagioclase on a very small scale.

Two thin sections were cut of samples from a zone in gneiss on western Qôrsungnitsoq. The gneiss here is a banded gneiss similar in appearance to the banded gneisses commonly found in the Egedesminde complex, but has bands of a granular gneiss that are reminiscent of gneisses of the Isortoq complex. A thin section of a sample from a granular gneiss band (88006) shows a quartz dioritic gneiss with hornblende and diopside. A very small amount of microcline is present as a seam between the boundary of a quartz grain with plagioclase grains, and is clearly secondary. A section of a sample of the main gneiss type (88007) shows microcline present as discrete grains forming an essential part of the rock. The microcline is subordinate in amount to plagioclase.

Although many thin sections were cut of samples from the brown gneisses and basic bands in them, only a few of these were found to contain hypersthene. The mafic minerals are mainly green hornblende, diopside and biotite. The main features that distinguish the rocks in this part of the Isortoq complex from the gneisses of the Egedesminde complex are 1) the brown colour, visible both in outcrop and in hand specimen and 2) the composition, which is quartz dioritic.

A feature of several thin sections of rocks from the south side of the island of Qôrsungnitsoq is the presence of some unusually large zircon crystals, which sometimes show zoning. One zoned zircon measures 0.16 $\mathrm{x} 0.10 \mathrm{~mm}$ (thin section 88011 ). 
Metadolerites and discordant amphibolites

Several bodies of metadolerite and discordant amphibolite were found in the eastern part of Sydostbugt. All of these are too small to be represented on any but a large-scale map. Their position is, however, shown on the present map.

Metadolerites were found on the southern side of the Kangilinâq peninsula, on the eastern end of the island of Akugdlift and a small island in the channel to the east, and on a small island on the north-west side of Sârdlat island. The form of the bodies varies. That on Kangilinâq is a subcircular body about $40 \mathrm{~m}$ in diameter. The metadolerites on the island east of Akugdlit form a number of disconnected bodies, aligned in such a way as to suggest very strongly that they are represent a broken-up dyke, with NW trend. The metadolerite on the island near Sârdlat forms a dyke.

In their central part these bodies are composed of a compact, dark rock with a distinct igneous appearance. There are occasional veins of quartz or pegmatite. In places the marginal rock is distinctly finer-grained than the central part. Some of the marginal rock shows a foliation parallel to the contact. At some places there is a discordance between the margin of the body and the foliation in the surrounding gneiss, but at many places there is concordance. The margin of one of these bodies on the eastern side of Akugdlit shows clear evidence of strong deformation, and much of the concordance seen is probably a secondary feature.

Thin sections of samples from the central part of some of these bodies show that the rocks are fine-grained garnetiferous metadolerites, with grain size mainly below $1 \mathrm{~mm}$. Some of the sections show well preserved relic igneous texture (see fig. 3). Some of the original plagioclase grains remain as cloudy, in places seriticized, laths with corroded outlines, sometimes forming a network, the interstices of which are filled with green hornblende derived by alteration of pyroxene, but in other places the plagioclase is present as aggregates of recrystallized grains. Garnet is prominent, forming up to about $5 \%$ of the rock, and is concentrated in the plagioclase. 


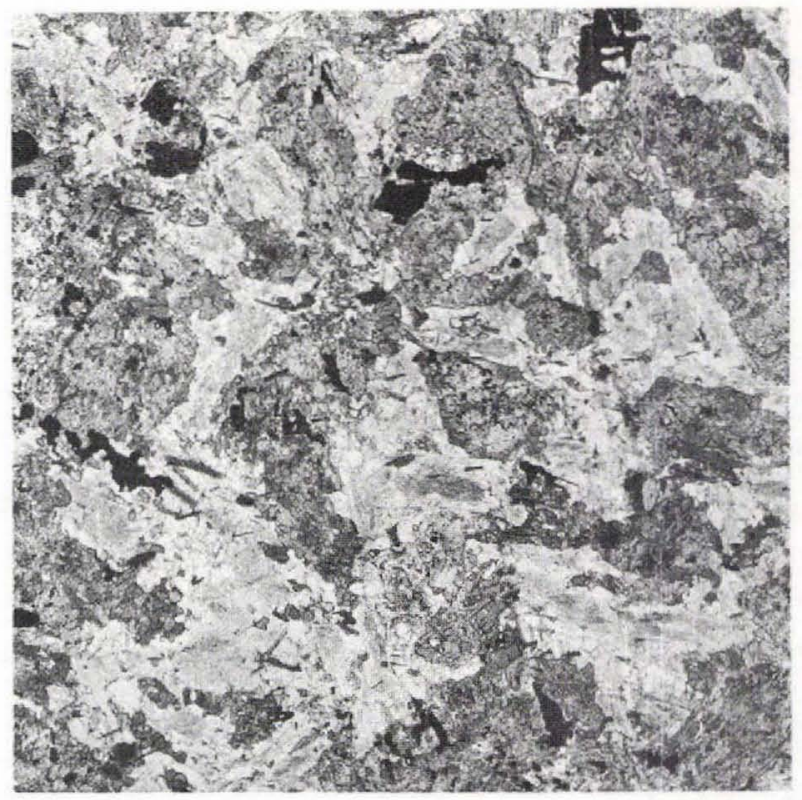

Fig. 3. Garnetiferous metadolerite from south side of Kangilinâq peninsula. Note the well preserved igneous texture. GGU sample 87941. Daylight. $\times 14$. (Photo: H. Micheelsen.)

Thin sections $(87937,87938)$ of the fine-grained rock from the margin of a body on the island east of Akugdlit show that this rock has completely recrystallized, and that the small grain size is not a direct reflection of chilling in the marginal zone. The rock shows a distinct foliation parallel to the margin. It may well be that the small grain size is partly or wholly the result of deformation followed by recrystallization of the marginal rock. Whether or not the present grain size could to some extent reflect recrystallization of rocks that were originally finer-grained because they were situated in a chilled marginal part of the intrusion cannot be stated.

The Sydostbugt metadolerites originally crystallized under normal magmatic conditions (the relic texture is evidence of this) and have subsequently been metamorphosed, with deformation and recrystallization of the marginal part and partial recrystallization and formation of garnet in the central part. 
Discordant amphibolite sheets were observed in the southern part of the island of Qeqertasugssuq. The sheets are all less than $1 \mathrm{~m}$ thick. They are completely discordant to the banding in the gneiss and also cut pegmatites. They are not themselves cut by any veins.

A thin section of a sample (87940) from one of these sheets shows the rock to consist mainly of hornblende and plagioclase, with subordinate biotite and ore. The rock has a strong directional fabric and there is no trace of any relic igneous texture.

Lamprophyre dyke

One lamprophyre dyke, the only one of its kind in the entire area, was found on the coast to the north-east of Jakobsholm island. Its position is shown on the map. The dyke, which shows an echelon development, cuts gneiss with amphibolite and pegmatite. It is not itself cut by later veins. Its maximum width is $10 \mathrm{~cm}$.

The dyke has a fine-grained margin a few millimetres in width, which is light green in colour. In thin section (87921) this marginal part can be seen to consist mainly of a mosaic of untwinned orthoclase with a patchy extinction and diopside grains, with subordinate amounts of apatite and sphene. There are a few grains of hornblende. Most of the grains are in the size range $0.1-0.5 \mathrm{~mm}$. The part away from the margin contains hornblende, which is strongly pleochroic in shades of green to light brown, biotite, carbonate, an unidentified brown pleochroic biaxial mineral, diopside and orthoclase. The hornblende is highly poikilitic and individual grains are up to several millimetres across. The orthoclase is interstitial. Apatite is abundant. Sphene is common, and there are grains of yellow pleochroic epidote. The section shows an increase in grain size from the marginal part inwards, the incoming of hornblende in quantity in the zone immediately adjacent to the margin being coincident with a marked increase in grain size. The texture of the zone away from the margin is not a normal magmatic texture.

A section from the centre of the dyke (87923) has the same mineral assemblage as the part away from the margin in the section described previously, except that carbonate is not present. The rock is strongly 
inhomogeneous. In part it is fine-grained and consists of untwinned or thoclase with a patchy extinction and $2 \mathrm{~V} \alpha$ ranging from $61^{\circ}$ to $68^{\circ}$, diopside, abundant apatite, and sphene. Other areas consist of aggregates of diopside with some sphene, and interstitial aggregates of orthoclase with abundant apatite. Some areas are rich in hornblende, which is extremely poikilitic. This section does not show a normal magmatic texture either; the texture is more like the texture of some metamorphic rocks.

The potash feldspar was separated. Diffractometer analysis by $J$. R $\phi$ nsbo confirmed that it is monoclinic. Optical spectrograph analysis by $\mathrm{H}$. Bollingberg showed that the $\mathrm{Na}_{2} \mathrm{O}$ content is about 2 per cent, which corresponds to about 10 per cent albite.

In the field the dyke can be seen to be undeformed and, as mentioned, it is not cut by any later veins, but itself cuts gneiss with pegmatite. Although the texture is clearly not a normal magmatic texture it cannot be shown that the dyke has recrystallized. The rock may be a magmatic rock that has crystallized under unusual conditions. It may be that detailed mapping will reveal the existence of more dykes of this type in the area. In the meantime, the one small dyke found must remain as an interesting curiosity.

\section{Dolerite dykes}

Several dolerite dykes, possibly of Tertiary age, were observed in the area. In addition to these, there is an unusual composite globule dyke which has been described by Ellitsgaard-Rasmussen (1952). The peculiar texture of this dyke indicates crystallization under special conditions, possibly in the presence of water. It has however, the mineralogical composition of a dolerite and has been grouped together with the dolerite dykes. It has a N-S trend and a maximum width of over $50 \mathrm{~m}$ at the northern end, and can be traced from west of Akúnâq in the north to the southern side of the entrance to Arfersiorfik in the south.

A dolerite dyke with a maximum width of $15 \mathrm{~m}$ and $\mathrm{E}-\mathrm{W}$ trend was traced from the west side of the bay Orpigsôq to just north of the 
settlement of Akugdlît. In thin section (87931) it can be seen to be a fineto medium-grained rock with a subdoleritic texture. Laths of zoned plagioclase up to $3 \mathrm{~mm}$ in length form a network enclosing aggregates of pyroxene grains, the individual grains usually being less than $1 \mathrm{~mm}$ across. Two pyroxenes are present. Zoned augite is the predominant pyroxene, but many of the augite grains are moulded on partly altered pigeonite with $2 \mathrm{~V}=0^{\circ}$ or very close to $0^{\circ}$. Grains of Fe-Ti oxides occur throughout the section. There is a small amount of interstitial quartz present.

A dolerite dyke, also with $\mathrm{E}-\mathrm{W}$ trend, and a width of $8 \mathrm{~m}$ cuts the southern tip of the island of Sârdlat, south-west of Akugdlît.

A NNE-trending dolerite dyke occurs at Manermiut, in the west of the area, and farther north a dolerite dyke with a NNW trend cuts across a promontory on the south-west end of the island Qârajugtuaraq.

\section{STRUCTURE}

At least two, and probably three, deformation phases are represented in the area.

Evidence in support of the existence of an early system of tight folds can be seen in the inner part of Kangersuneq fjord. The outcrop pattern of the intercalated schists and gneiss in this area suggests strongly that a later system of upright to steeply inclined folds with NE-trending axial planes has been superposed on a large tight fold with closure towards the head of the fjord and an axial plane that originally dipped gently east.

A large tight fold is visible in the cliffs on the north side of the fjord in the middle of a wide schist belt. The trace of the axial plane of this fold on the cliffs shows a very gentle dip upfjord. The geometry of this fold is not known, but plotting of the trace of the fold on a map makes it clear that it cannot belong to the main phase of deformation, which in this area is represented by upright to steeply inclined NE-trending folds. It could well belong to the earlier folding postulated in this area. 

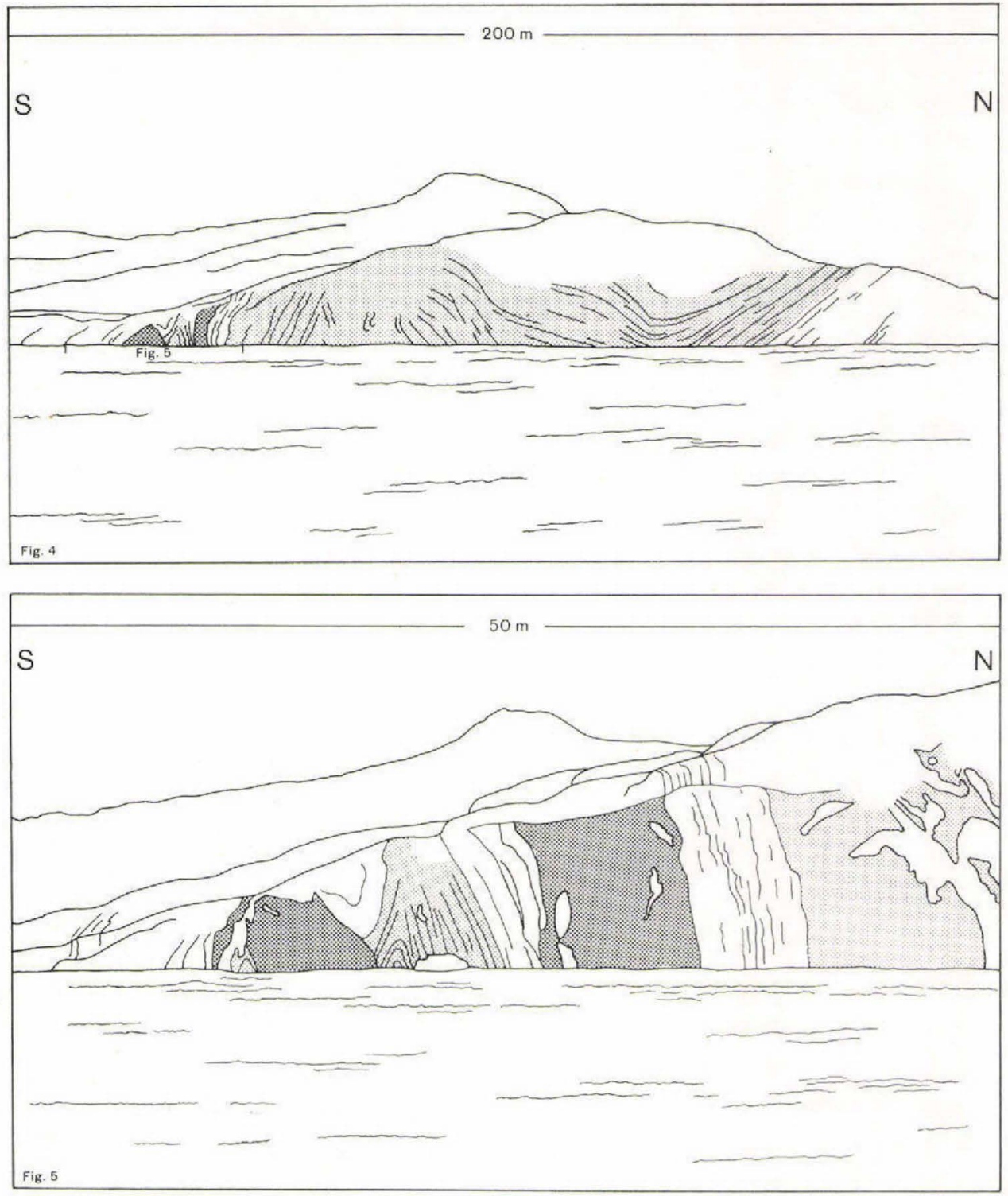

Fig. 4. Eastern end of Akuliaruserssuaq peninsula.

Fig. 5. Close up of part of coast section in fig. 4. Light shading: areas of highly migmatitic pelitic gneiss and mica schist. Dark shading: amphibolite. Unshaded: pegmatoid bands and bands of leucocratic gneiss. Note contrast in fold style between the northern and southern parts of the section. (Drawn from colour transparencies.) 
The map shows that the area as a whole is dominated by trends lying mainly between $\mathrm{NE}$ and $\mathrm{E}-\mathrm{W}$. The elements giving rise to this strong structural grain are discrete bands, mainly mica schist and amphibolite, and compositional banding in the gneiss. The trends are the result of the main phase of deformation.

In parts of the area this deformation phase is expressed by upright to steeply inclined folds, with axial planes trending between NE and $E-W$, and plunges that are gentle to moderate in amount. The style of the folding is clearly seen in two areas, the Ikamiut area and the peninsula south of Christianshåb.

Figs. 4 and 5 show the style of folding at the end of the peninsula Akuliaruserssuaq south of Ikamiut. The rocks involved in the folding are quartzo-feldspathic gneiss, pelitic gneiss, mica schist and amphibolite. The central part of the peninsula consists mainly of pelitic gneiss and mica schist, with minor amounts of amphibolite. The rocks in this part contain abundant folded pegmatoid and leucocratic gneiss bands, which in places consitute more than half of the rock (see fig. 6). The quartzo-feldspathic gneiss is also migmatitic, but the migmatite is of a more diffuse type. The folds here plunge due $W$ at $10^{\circ}$. As can be seen from the sketch the inter-limb angles of the major folds vary, the folds ranging from open to tight, and there is a considerable difference in the dimensions of the fold profiles.

The rocks in the peninsula south of Christianshåb have been strongly folded. One major fold, the fold at the head of the inlet Kangerdluluk, is isoclinal. The schists at the south-western end of the peninsula have abundant minor folds in them (see fig. 7). They contain numerous pegmatites, which in places are rodded, the axes of the rods being parallel to the fold axes, which have a low to moderate plunge NE in this area.

The fjord system Kangersuneq-Orpigsôq straddles folds plunging $\mathrm{NE}$ to $\mathrm{E}$ and comprising, from north to south, an antiform, a synform and an antiform. It is clear that the folds here are of open type, with large, but varying dimensions.

It seems that while the folds associated with this main deformation phase have certain features in common, there are also important differences. They all have steeply dipping to vertical axial planes and axial plane trends lying between $\mathrm{NE}$ and $\mathrm{E}-\mathrm{W}$, but the dimensions and inter-limb angles vary considerably. 


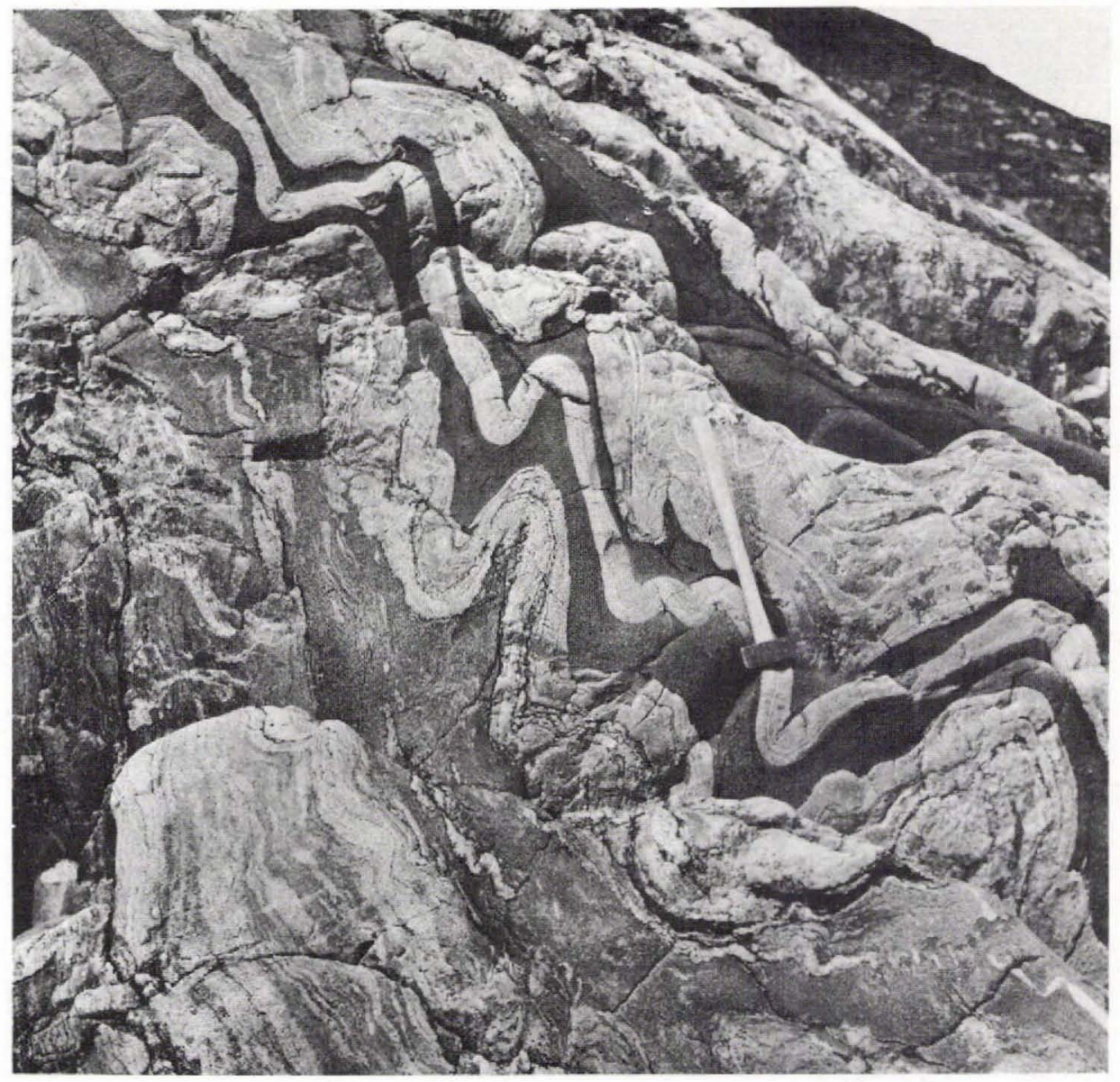

Fig. 6. Folded migmatite. Dark bands are biotite amphibolite. Grey bands are biotite gneiss. Note banding in the leucosomes. East end of Akuliaruserssuaq peninsula. (GH. 03.08.1966.)

Although the complete structural pattern of this main phase of deformation will only emerge after detailed mapping, enough evidence has been obtained to show that it would be incorrect in this area to refer to it as a folding phase alone. This is important because of the structural pattern that is emerging from the Nagssugtoqidian fold belt as a whole as a result of the compilation work for the 1:500000 map of West Greenland at present being undertaken by A.Escher. In the Egedesminde-Christianshåb area 


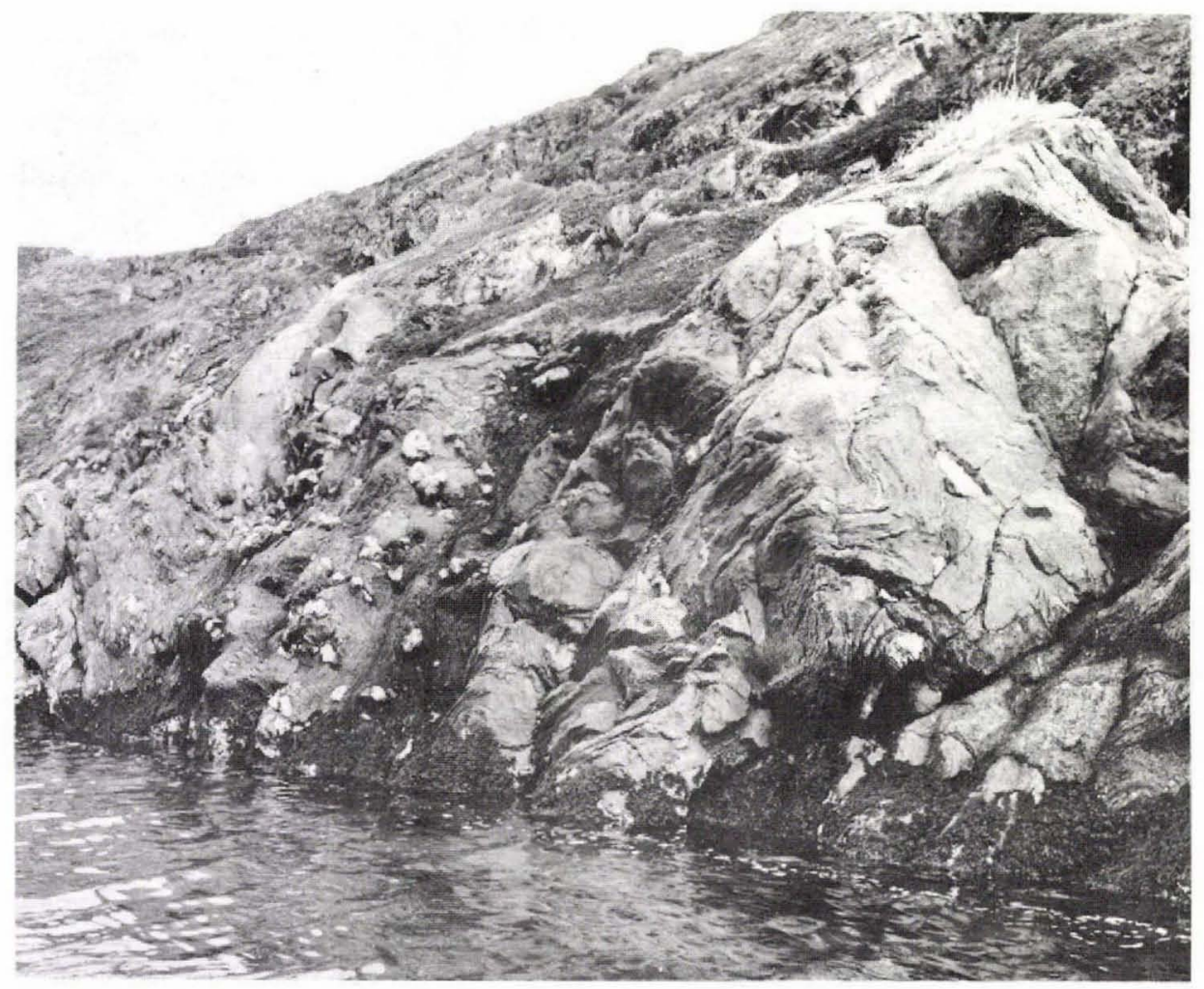

Fig. 7. Rodding in migmatite. Strongly folded mica schist with pegmatoid rods. South-west end of Kangilinâq peninsula. (GH. 01.07.1966.)

there are certainly many large and small folds associated with this deformation, particularly in the area around Sydostbugt, but there are extensive tracts of country in which there are no major folds. It is possible to sail from the channel Sarfârssuk in the inner part of Arfersiorfik fjord to the northern side of Tasiussarssuaq without seeing one major fold, and no major fold is visible on the aerial photos of the whole of this area except for a single fold affecting an amphibolite band at the inner end of the fjord Qardlutôq. This area consists mainly of granodioritic gneiss, but this is often well banded, and there are several amphibolite bands. Any largescale folding should thus be readily discernible both in the field and on aerial photos, but this area is obviously lacking in the sort of folding characteristic of the area farther to the north. The strikes range from 
ENE to ESE and the dips are mainly moderate northwards in the whole of this tract of country.

Another type of expression of this main deformation phase can be seen in the fjord Amitsuarssuk west of Ikamiut. The rocks here consist of granodioritic gneiss with mica schist and amphibolite bands on the north side of the fjord and amphibolite bands and lenses on the south side. Minor folds are present and plunge gently WSW. Along part of the southern side of the fjord the gneiss shows large-scale linear structures, whose axes are are parallel to the axes of the minor folds. These linear structures are expressed on the aerial photos by lineaments.

Mineral lineation due to preferred orientation of hornblende crystals was observed at several places in the quartz diorite body in Arfersiorfik fjord, but was not seen in the part of the body where hypersthene is still preserved. Insufficient measurements were obtained to enable its significance in terms of the regional structure to be assessed.

In the southern half of the map there are a number of Z-shaped folds that have resulted in a dextral shortening of bands along trends ranging from ENE to ESE. The most striking example is the large fold in the area east of the fjord Tunorssuaq. This fold is very clearly expressed by amphibolite in the gneiss. The main fold is $Z$-shaped. The northern closure faces $\mathrm{E}$ and plunges $\mathrm{E}$. The southern closure faces $W$. Dips in the gneiss west of the closure suggest a gentle plunge $E$, but dips at the contact of the gneiss and amphibolite at the closure are vertical. A subsidiary fold is developed on the northern flank of the main fold. This also expresses a dextral shortening.

The fold affecting the western end of the amphibolite band east of the fjord Qardlutôq is also Z-shaped, as is the large intrafolial fold on the southern side of the island of Qôrsungnitsoq. It is possible that the form of the amphibolite along the southern side of Arfersiorfik fjord is the result of a dextral shortening. One major fold affects amphibolite in this area, but insufficient work has been done to elucidate the details of the structure here.

The evidence given suggests that a shear element has formed part of the main deformation phase in the southern half of the map. 
Evidence proving the existence of a late deformation phase can be seen south of Amitsuarssuk fjord. In this area a late fold has been superposed on folds associated with the main deformation phase, with the result that a typical eye fold has been formed. The existence of this late folding has only been proved by regional mapping, and its geometry is not known. However, the form of the eye fold suggests that the late fold has a NW-trending axial plane.

The folding associated with the main deformation phase here is clearly complex and the details have not been fully worked out. However, it is clear that there are isoclinal folds present on the southern side of the eye fold.

Only a few major faults were found in the area, but because the area was mapped rapidly and the different lithological units could not be followed readily on the aerial photos it is likely that faults are more numerous than suggested by the accompanying map. Some NNE-trending wrench faults were observed in the area west and south-west of Ikamiut. One of these, on the southern side of the bay Nivâp pâ, was proved to have a sinistral displacement of about $500 \mathrm{~m}$.

At two places evidence was found of repeated movements along faults. East of the inner part of Arfersiorfik fjord, south of the locality Eqalugârssuit taserssue, light-coloured quartzo-feldspathic gneiss is in contact with darker rocks forming part of the extensive quartz diorite body. The contact lies in a linear depression trending approximately $\mathrm{E}-\mathrm{W}$ and is not exposed, but on the south side of the depression the melanocratic rocks are veined by pseudotachylite, so that there is no doubt that the depression marks a fault. There are two generations of pseudotachylite. Early pseudotachylite veins have been folded and cut by later veins, which are not folded.

A short distance to the north of the end of Kangerdluluk a NNE-trending fault with a steep ESE dip cuts gneiss. There is considerable crushing along the fault and some pseudotachylite is present on the west side. A pegmatite has been emplaced in the crush zone. The margins of the pegmatite are crushed, but the centre is cohesive. There have probably been two periods of crushing here, separated by pegmatite emplacement. A small amount of superficial chrysocolla mineralization was observed in the rocks of this area. 


\section{METAMORPHISM}

Metamorphic facies

The main rock type in the Egedesminde complex is a gneiss of granodioritic composition, in which biotite and hornblende are the mafic minerals. Three main lithlogical types occur as bands in this gneiss: mica schist and pelitic gneiss, amphibolite, and marble and calc-silicate rocks.

The mica schists and pelitic gneiss round Sydostbugt are characterized by the following minerals: quartz, plagioclase, biotite, muscovite, garnet and sillimanite. One or more of these minerals may be lacking at individual localities, but these minerals are widely distributed in these rocks. In the northern part of the bay Nivâp pâ and south of Ikamiut, potash feldspar was found in addition to plagioclase in pelitic gneisses associated with the mica schists of this region. At a few localities south of Sydostbugt cummingtonite (Guinier analysis by $O$. V. Petersen showed this to be a manganiferous variety) is present in the schists. At one locality mica schists with staurolite and sillimanite were found (87991). The staurolite occurs as porphyroblasts showing poikiloblastic texture and the sillimanite occurs as large fibrous aggregates. The two minerals appear to be stable. Thin sections 112812 and 112813 of samples of pelitic gneiss from the southern side of the island of Anarsungnikât in the northern part of Nivâp pâ proved to contain small amounts of kyanite in addition to fibrous sillimanite, but it was not possible to determine the stability relations of these two minerals.

The amphibolites contain hornblende and plagioclase as the main minerals, but garnet, diopside, epidote and biotite occur in places. Quartz is also present in some of the amphibolites.

Tremolite, diopside and hornblende are found in the marble and calc-silicate bands.

The assemblages described show that the rocks have undergone amphibolite facies metamorphism. If the assemblage that is so widespread in the schists round Sydostbugt is stable, the coexistence of 
muscovite and sillimanite would indicate a facies series where the operating pressure has been lower than in the Barrovian-type facies series (see Winkler, 1967, p. 112). The coexistence of staurolite and sillimanite in schists at one locality would also fit in with this concept. It can therefore be said that, in areas where diagnostic assemblages are present, the assemblages are indicative of the middle of the amphibolite facies, but also suggest an intermediate facies series with lower operating pressures than those in the Barrovian type of metamorphism.

The main rock type in the part of the Isortoq complex examined by the writer is a gneiss of quartz dioritic composition. Bands and lenses of amphibolite are common in the gneiss. The main differences between this gneiss and the gneisses of the Egedesminde complex are 1) the brown colour, visible both in outcrop and in hand specimen, 2) the mineralogical composition - the rocks are quartz dioritic - and 3) the presence of hyper sthene in some bands. The presence of hypersthene shows that these brown gneisses have originally crystallized under granulite facies conditions, but the reason for the apparent scarcity of this mineral is not known. In most of the samples sectioned green hornblende, diopside and biotite are the mafic minerals present. There are two possible explanations for this: 1) the bulk composition of the rocks may have been unsuitable for the widespread development of hypersthene, or 2) hypersthene may have originally been more abundant and its relative scarcity may reflect some downgrading of these gneisses. Windley (1966) describes areas in southern West Greenland where there has been widespread retrograde metamorphism of granulite facies gneisses.

The boundary relations between the Isortoq and Egedesminde complexes have already been referred to. Characteristic of the boundary area on the northern side of Arfersiorfik fjord is the presence of zones of light-coloured, often lit-par-lit banded gneisses, which are intercalated with the darker, brown gneisses. These light-coloured gneisses are rich in microcline.

The part of the Isortoq complex visited by the writer seems to be all a marginal zone. In view of this no attempt will be made to reach a conclusion on the reasons for the phenomena just described; more work would be required on the complex as a whole. 
Migmatites

Migmatitic development is very characteristic of much of the schist and pelitic gneiss in the area around Sydostbugt. With the object of studying the mineralogy of these migmatites, the writer collected a number of samples during a brief visit to the area in 1968. Samples were collected from the paleosomes and from the neosomes. In order to facilitate the identification of potash feldspar, all thin sections and hand specimens were etched and then treated with sodium cobaltinitrite.

The localities examined were two small islands in the north of the bay Nivâp pâ, Anarsungnikât and Sagdlerssuaq, and the eastern end of the peninsula Akuliaruserssuaq, south of Ikamiut.

The rocks on Anarsungnikât consist of pelitic gneiss with numerous leucocratic seams. Quartz, feldspar, garnet, biotite, muscovite and sillimanite can be identified in the outcrop and the last three of these minerals were seen to occur together in one band. The samples from this island comprise almost entirely material from the paleosomes.

A thin section of one sample (112811) shows pronounced retrograde effects. Brown biotite shows all stages of alteration to a chlorite with a neutral colour. In part of the slide the chlorite is closely intergrown with potash feldspar. Both minerals are clearly replacing biotite, but chlorite unassociated with potash feldspar is also found. Sphene occurs in these intergrowths in places; it has irregular outlines and is of secondary origin. There is partial replacement of plagioclase by potash feldspar and sericite; the two minerals are closely associated. In one plagioclase crystal the replacement has proceeded along the twin lamellae. Potash feldspar also forms a vein cutting across the section. The potash feldspar has a very patchy extinction and does not show the cross-hatched twinning often seen in microcline. Muscovite is present, but is subordinate to total chlorite and biotite in amount. It appears to be stable. Tourmaline is a prominent accessory mineral. There are minor amounts of opaque material and apatite.

A nother sample from this island (112812) is of a pelitic gneiss with garnet, sillimanite and biotite. The hand specimen contains a thin $(1 \mathrm{~cm})$ leuococratic seam in which partial replacement of plagioclase by 
potash feldspar can be seen. In thin section the biotite shows partial alteration to chlorite, but the alteration is much less advanced than in the other section. Some partly altered biotite flakes have associated potash feldspar. The plagioclase in this rock is relatively fresh, with only incipient replacement by sericite and potash feldspar. Typical cross-hatched twinning is not shown by the potash feldspar. Muscovite is present in very minor amounts. Sillimanite is present in the form of fibrolite in part of the slide. There are a few grains of garnet. Tourmaline, zircon, opaque material and apatite are minor constituents.

Both sample 112812 and sample 112813 of a pelitic gneiss from the same locality proved in thin section to contain small amounts of kyanite in addition to fibrous sillimanite, but it was not possible in these sections to determine the stability relations of the two aluminosilicates.

A sample (112814) was collected from a garnetiferous pelitic gneiss on the western end of the island of Sagdlerssuaq. The sample has a pegmatoid band with tourmaline crystals. The thin section covers the boundary between the pelitic gneiss and pegmatite. The pelitic gneiss consists mainly of quartz, plagioclase, biotite and garnet. A small amount of muscovite is present. Tourmaline and apatite are accessory minerals. The biotite is relatively fresh, but there is local chloritization. Plagioclase shows some replacement by potash feldspar and sericite; in one grain replacement has proceeded along twin lamellae. The potash feldspar does not show cross-hatched twinning. Garnet is present as porphyroblasts with poikiloblastic texture.

The pegmatoid part consists of quartz and plagioclase. The zone adjacent to the pelitic gneiss is quartz-rich, and consists of a mosaic of quartz grains showing strain extinction. The plagioclase shows slight sericitization unaccompanied by development of potash feldspar.

A second sample (112815) from the same area consists of garnetiferous pelitic gneiss with a pegmatoid lens. A thin section was cut of the pegmatoid part. This consists largely of quartz and plagioclase, with subordinate biotite (partly chloritized), muscovite and garnet. Tourmaline is present as an accessory mineral. The plagioclase shows some sericitization and there is some replacement by saussurite. A minute amount of potash feldspar is present replacing plagioclase. 
The general structure and distribution of rock types at the end of the Akuliaruserssuaq peninsula can be seen on figs. 4 and 5 . A sample (112817) was collected from garnet-mica schist from the axis of the synform. A thin section shows the rock to consist essentially of quartz, plagioclase, brown biotite and garnet. The biotite is not chloritized. The plagioclase is relatively fresh, with only a trace of sericitization. There is a very small amount of potash feldspar in the section. Garnets are present as porphyroblasts showing poikiloblastic texture, with inclusions of quartz and biotite. Apatite, zircon and opaque material are present in minor amounts.

A thin section of a sample of granular quartzo-feldspathic rock (112818) from a leucosome in the schist shows the rock to consist almost entirely of quartz and plagioclase. Chlorite, muscovite and garnet are present in small amounts. There are a few shreds of biotite. Clinozoisite is present replacing plagioclase. Apatite is present as an accessory mineral. The plagioclase is somewhat sericitized; a very small amount of potash feldspar is associated with some of the sericite.

The part of the migmatite zone immediately to the south of the synformal axis contains some very thin amphibolite bands. A thin section of a sample from one band (112820) shows the rock to consist essentially of hornblende, biotite, plagioclase, quartz and sphene (some of which shows crystal outlines). There is a small amount of opaque material. Apatite is present as an accessory mineral. Apart from slight sericitization the plagioclase is fresh. A minute amount of potash feldspar is associated with sericite replacing plagioclase.

A sample (112821) was collected from a leucocratic band in the amphibolite. In thin section this can be seen to consist mainly of quartz and plagioclase, with a small amount of biotite, chlorite and muscovite. Zircon is present as an accessory mineral. Some of the biotite flakes are partly chloritized. The chlorite is weakly pleochroic, from pale green to neutral. The plagioclase is slightly sericitized and a little carbonate is developed. No potash feldspar is present.

A sample (112824) was collected from a band of pelitic gneiss north of the larger of the two tight folds shown in fig. 5. A thin section shows the rock to consist of quartz, plagioclase, potash feldspar, biotite and muscovite, with zircon as an accessory mineral. Biotite and muscovite 
are stable. The two minerals are intergrown in places; in one place the minerals are intergrown by interdigitation along the cleavage. Some of the muscovite is developed as interstitial "trains" along the boundaries of quartz and plagioclase grains. Apart from very slight sericitization the plagioclase is unaltered. Some myrmekite is present where plagioclase is in contact with potash feldspar. The potash feldspar is present as areas with irregular outlines and as aggregates of grains. Some of it shows the well developed cross-hatched twinning typical of microcline.

Sample 112825 was collected from a coarse leucocratic gneiss band in the same area as 112824 . In thin section it can be seen to consist of quartz, plagioclase and potash feldspar, with some muscovite, biotite and fibrous sillimanite. Muscovite is in places intergrown with plagioclase, potash feldspar and biotite. Sillimanite is restricted to one area with irregular outlines, where it occurs as abundant very thin fibres embedded in muscovite. Potash feldspar is present as sinuous, optically continuous areas with very irregular outlines. Some of it shows prominent crosshatched twinning. The plagioclase is relatively fresh. Some myrmekite is developed along boundaries between plagioclase and potash feldspar.

In the same area there are bands of leucocratic garnetiferous gneiss with sillimanitic nodules. The nodules are sub-circular, and some of them exceed $3 \mathrm{~cm}$ in diameter (112826 and 112827). In hand specimen garnet can be seen to occur as scattered clusters of crystals and along foliation planes. Garnets penetrate the marginal part of a nodule in one sample (112827). The host rock has a granitic composition, and can be seen in thin section (112827A) to consist of quartz, potash feldspar (abundant, with well developed cross-hatched twinning), plagioclase, biotite, muscovite and garnet. Biotite and muscovite are commonly intergrown; in general both minerals appear to be stable, but there are a few intergrowths where the texture could suggest a replacement of biotite by muscovite. The plagioclase is relatively unaltered, except for slight sericitization. Some myrmekite is developed where plagioclase is in contact with potash feldspar.

The nodules consist essentially of quartz, sillimanite and muscovite, in order of abundance. A few grains of zircon are present. Sillimanite occurs as felted mats of fibres and as innumerable individual fibres 
embedded in quartz. In one nodule (thin section 112827A) the sillimanite is associated with abundant muscovite; in another nodule in the same sample (thin section 112827B) muscovite is only a minor constituent. Sillimanitic nodules of this type have recently been described by Losert (1968), who considers them to have originated by a process of dealkalization.

The foregoing description covers an area of migmatite development in pelitic gneiss. Unfortunately, lack of material has prevented a similar study being made of the migmatites that are so commonly found in areas of mica schist. A very common development in mica schists is the presence of numerous small quartzo-feldspathic seams and lenses along the foliation of the schist. The appearance of these seams and lenses in the field suggests strongly that they have originated in situ by metamorphic differentiation. Their mineral assemblage appears to be very close to that of the schists, except that the proportions of the various minerals are very different.

In the pelitic gneisses studied, the leucocratic bands have a mineral assemblage very similar to that of the host rocks. From this point of view, these neosomes could have originated in situ by metamorphic differentiation.

There are two types of potash feldspar development in the migmatite zones studied. In the islands Anarsungnikât and, to a lesser extent, Sagdlerssuaq, potash feldspar is clearly a secondary development and is related to breakdown of biotite. In part of the Akuliaruserssuaq section, the host rocks are quartz dioritic in composition as are the neosomes, but in the southern part of the section potash feldspar is present in considerable amounts as an essential component of the host rock and neosomes. The potash feldspar here is typical microcline and muscovite is still stable, so the different development in this area does not reflect a higher grade of metamorphism. The metamorphic facies cannot be above the middle of the amphibolite facies. 


\section{COMPARISON WITH ADJOINING AREAS}

The Egedesminde complex extends to the north and to the south of the present map. The area to the north is described by Escher and Burri (1967). The dominant rock type immediately to the north is a biotite gneiss, mainly of granodioritic composition, with prominent amphibolite bands and subordinate pelitic schist. In this respect the rocks are similar to those found in the northern part of the present map. Quartzite layers occur in the gneiss south of Claushavn. No quartzite was found in the area mapped by the present writer, nor were any rocks found that could correspond to the siliceous gneiss of the Rodebay area.

Escher and Burri recognize three phases of deformation in the southern gneisses of the area to the north.

The earliest phase is represented by isoclinal minor folds with axial trends mainly between NW and NNE. The next phase, which is also the main phase, is represented by major and minor folds whose axial directions are $\mathrm{NE}$ to ENE, with steeply dipping axial planes. Most of the folds are close to isoclinal folds. The last phase has resulted in a local buckling of the axial planes of the folds of the main phase, and in some places has also changed the plunge of the axes of these folds. The axial trend of these latest folds appears to vary between N and NW. The structural development is thus very similar to that of the Egedesminde-Christianshåb area.

The rocks that make up the island group extending from Anârssuit to Eqûtit kangigdleq, north-east of Egedesminde, have been described in detail by Ellitsgaard-Rasmussen (1954). The rocks are metasediments and greenstones. They were included in the Egedesminde complex by Noe-Nygaard and Ramberg (1961). The metasediments comprise schists and, in the Anârssuit-Isuamiut group, quartzites. The schists in the Eqûtit kangigdleq group are staurolite-bearing schists, while in the other islands they are garnet-mica schists without staurolite. Staurolite was only found at one locality in the area mapped by the writer to the south and east where it occurs together with sillimanite. Sillimanite is common in many of the areas of mica schist seen by the writer, but does not occur in the above- 
mentioned island group. The grade of metamorphism is higher in the metasediments of the Eqûtit kangigdleq group than in those in the other islands; the mineral assemblages in the island group as a whole indicate a lower grade of metamorphism than in the area mapped by the writer. Neither greenstones of the type described by Ellitsgaard-Rasmussen nor rocks that could be shown to represent a higher-grade equivalent were found in the area to the south and east.

The part of the Egedesminde complex flanking the sides of the innermost part of Arfersiorfik fjord, south of the accompanying map, was visited by the writer in 1966 . The quartz diorite body continues into this area, where it overlies light-coloured gneiss of granodioritic composition with some amphibolite bands. Escher (1966) mapped a very large area south of the accompanying map. The area comprises rocks belonging to the Egedesminde, Isortoq and Ikertoq complexes (Ramberg, 1949).

In the southern part of the Egedesminde complex Escher recognized one major folding with axial trend ENE. In the Isortoq complex he recognized a north and south unit, affected probably by the same two successive deformations which folded the Ikertoq complex to the south (ENE and NW axial trends), and a central unit which shows in addition the effects of an earlier deformation. The major folding recognised by Escher in the Egedesminde complex corresponds to the main phase of deformation found in the present area. The two, and locally three, deformations recognized in the Ikertoq complex are probably directly comparable to the three deformation phases postulated in the Egedesminde-Christianshab area.

Escher notes the presence of a major tectonic disturbance between the rocks of the Ikertoq complex and those of the Isortoq complex, which probably represents a thrust zone more or less concordant with the foliation of the gneisses. He states that structural evidence suggests that there may have been dextral wrench movements along the fault zone.

In the Agto area, some distance to the south-west of the present map, rocks of both the Egedesminde and Isortoq complexes are represented. Bondesen (1968) has distinguished three structural units, an upper unit and two lower units. The folding of all three units is controlled by ENE-trending axes refolded by NW-trending steeply plunging fold axes, but the lower structural units show a more complex development due to additional fold phases. He mentions that in the north and south of the area mapped the regional structural picture is different, NNE fold trends being dominant. 
Jensen (1968) has observed pseudotachylite in several localities in the Agto area. He states that most pseudotachylite localities were found along an area in the middle of which a diorite was emplaced before granulite facies conditions were reached. This diorite appears to be a continuation of the large quartz diorite body mapped in the inner part of Arfersiorfik fjord, and it may be noted that the present author found pseudotachylite at one locality along the northern margin of this body.

It can thus be seen that there are many similarities between the area mapped by the writer and the adjoining areas. 


\section{REFERENCES}

Bondesen, E. (1968) Research on the high-metamorphic complexes of the Agto area. Rapp. Gronlands geol. Unders., Nr. 15, 19-21.

Ellitsgaard-Rasmussen, K. (1952) A West Greenland globule dike. Meddr dansk geol. Foren., Bd. 12, Hft. 1 [for 1951], 83-101.

Ellitsgaard-Rasmussen, K. (1954) On the geology of a metamorphic complex in West Greenland. Bull. Grønlands geol. Unders. , No. 5 (also Meddr Grфnland, Bd. 136, Nr. 6).

Escher, A.(1966) New geological reconnaissance mapping in the area between Nordre Strømfjord and Ikertoq fjord. Rapp. Grфnlands geol. Unders., Nr. 11, 24-25.

Escher, A. and Burri, M. (1967) Stratigraphy and structural development of the Precambrian rocks in the area north-east of Disko Bugt, West Greenland. Rapp. Grфnlands geol. Unders., Nr. 13.

[Giesecke, K. L.] (1910) Karl Ludwig Gieseckes mineralogisches Reisejournal über Grönland, 1806-1813. Meddr Grфnland, Bd. 35.

Henderson, G. (1966) Field mapping in the Egedesminde-Christianshåb area (sheets 68 V.1 and 68 V.2). Rapp. Grфnlands geol. Unders., Nr. 11, 17-19.

Jensen, V. (1968) Pseudotachylite in the Agto area. Rapp. Grønlands geol. Unders., Nr. 15, 22-23.

Larsen, O. and M $\phi$ ller, J. (1968) K/Ar age determinations from western Greenland I. Reconnaissance programme. Rapp. Grønlands geol. Unders., Nr. 15, 82-86.

Losert, J. (1968) On the genesis of nodular sillimanitic rocks. Rep. 23rd Intern. geol. Congr. Czechoslovakia, Section 4, 109-122.

Noe-Nygaard, A. (1944) Rapakivi fra Egedesminde Distriktet, Vestgr $\varnothing n-$ land. Meddr dansk geol. Foren. ,Bd. 10, 484-486.

Noe-Nygaard, A. and Ramberg, H. (1961) Geological reconnaissance map of the country between latitudes $69^{\circ} \mathrm{N}$ and $63^{\circ} 45^{\prime} \mathrm{N}$, West Greenland. Meddr Grфnland, Bd. 123, Nr. 5 . 
Ramberg, H. (1949) On the petrogenesis of the gneiss complexes between Sukkertoppen and Christianshaab, West-Greenland. Meddr dansk geol. Foren., Bd. 11, Hft. 3 [for 1948], 3i2-327.

Ramberg, H. (1951) Remarks on the average chemical composition of granulite facies and amphibolite-to-epidote amphibolite facies gneisses in West Greenland. Meddr dansk geol. Foren., Bd. 12, 27-34.

Ramberg, H. (1956) Pegmatites in West Greenland. Bull. geol. Soc.Amer., Vol. $66,185-213$.

Windley, B.F. (1966) Anorthosites and polymetamorphism between Ravns Stor $\varnothing$ and Sukkertoppen, West Greenland. Rapp. Grфnlands geol. Unders., Nr. 11, 27-29.

Winkler, H.G.F. (1967) Petrogenesis of metamorphic rocks. SpringerVerlag, Berlin. 
PRELIMINARY GEOLOGICAL MAP OF THE EGEDESMINDE - CHRISTIANSHÁB AREA

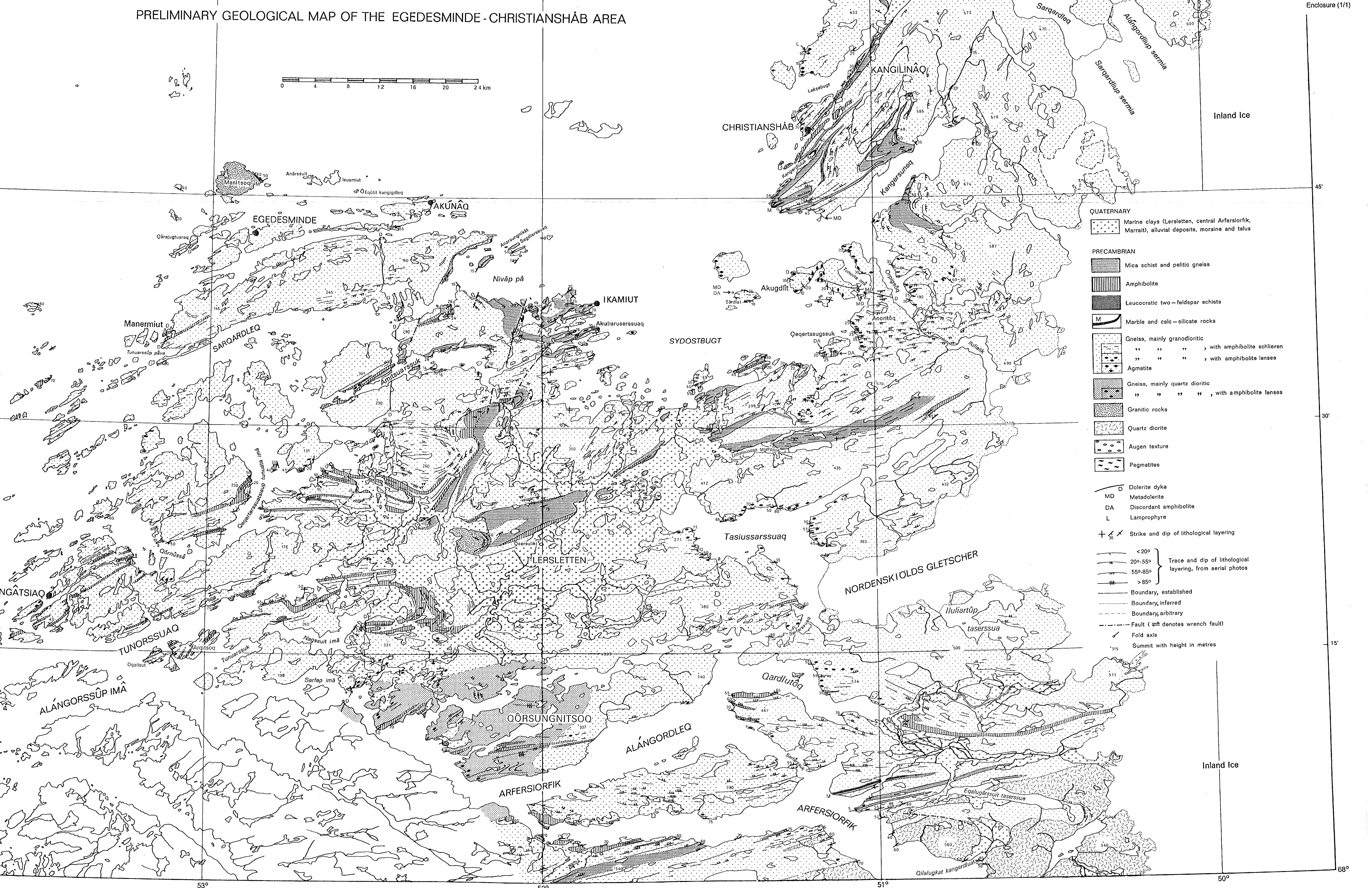
2. S.

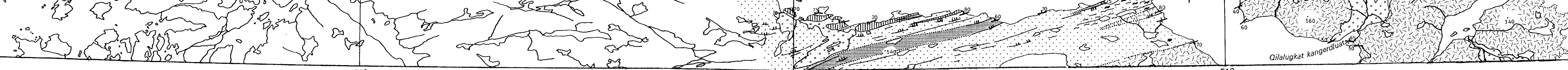




\section{Grønlands Geologiske Undersøgelse}

\section{Reports}

No. 10 Analytical procedures used in the Geochemical Laboratory of the Survey. 1967 by B. I. Borgen. D.kr. 4.00 .

No. 11 Report of activities, 1966. (Out of print).

No. 12 The chromite deposits of the Fiskenæsset region, West Greenland. 1967 by M. Ghisler and B. F. Windley. D.kr. 6.00 .

No. 13 Stratigraphy and structural development of the Precambrian rocks in the area north-east of Disko Bugt, West Greenland. 1967 by A. Escher and M. Burri. D.kr. 3.50.

No. 14 Petrology and geology of the Precambrian Gardar dykes on Qaersuarssuk, South Greenland. 1968 by W. S. Watt. D.kr. 4.00 .

No. 15 Report of activities, 1967. 1968. (Out of print).

No. 16 The geological setting and mineralizations west of Lilianmine, South Greenland. 1968 by M. Ghisler. D.kr. 4.00 .

No. 17 The Tartoq Group on Nuna qaqortoq and in the Iterdlak area, South-West Greenland, 1968 by A. K. Higgins. D.kr. 4.00 .

No. 18 Preliminary account of the geology of the Kvanefjeld area of the Ilimaussaq intrusion, South Greenland. 1969 by H. Sørensen, J. Hansen and E. Bondesen. D.kr. 6.00 .

No. 19 Report of activities, 1968. 1969. D.kr. 6.00.

No. 20 On the applicability of magnetic prospecting for chromite in the Fiskenæsset region, West Greenland. 1969 by M. Ghisler and P. Vallabh Sharma. D.kr. 3.50.

No. 21 Report on the 1968 geological expedition to Scoresby Sund, East Greenland. 1969. D.kr. 6.00 .

No. 22 Oil and gas prospects in the Cretaceous-Tertiary basin of West Greenland. 1969 by G. Henderson. D.kr. 6.00 .

No. 23 The Precambrian rocks of the Egedesminde-Christianshåb area, West Greenland. 1969 by G. Henderson. D.kr. 4.00.

Bulletins and Miscellaneous Papers are only available on exchange with institutions and libraries. Reports are obtainable on exchange, or may be purchased from Grønlands Geologiske Undersøgelse, Østervoldgade 10, Dk-1350 Copenhagen $\mathrm{K}$, Denmark. 
